\title{
Geography of Czech aid: Where and why Czechia promotes development?
}

ZDENĚK OPRŠAL, JAROMÍR HARMÁČEK, MIROSLAV SYROVÁTKA

Palacký University Olomouc, Faculty of Science, Department of Development and Environmental Studies, Olomouc, Czechia; email: zdenek.oprsal@upol.cz, jaromir.harmacek@upol.cz, miroslav. syrovatka@upol.cz

ABSTRACT This article analyzes the territorial allocation of Czech development assistance. The first part of the article (sections 2 and 3) provides an overview of the historical development and territorial aspects of Czech aid. The second part (section 4) employs regression analysis to examine the determinants of territorial allocation of Czech aid over the period 1998-2013. Czech aid flows to favoured countries in a relative proximity to Czechia and to the countries inherited from the communist era. The results of the regression analysis show that in most cases it was Czech economic and political interests that played a role in determining the allocation of Czech aid as well as some of the factors that reflect the recipients' needs and aid effectiveness.

KEY WORDS foreign aid - official development assistance - aid allocation - Czechia - emerging donor

OPRŠAL, Z., HARMÁČEK, J., SYROVÁTKA, M. (2017): Geography of Czech aid: Where and why Czechia promotes development? Geografie, 122, 2, 169-189.

Received June 2016, accepted December 2016.

(C) Česká geografická společnost, z. s., 2017 


\section{Introduction}

Since the fall of the communist regime in 1989, Czechia has made far-reaching economic and political reforms aimed at the creation of a market economy and democratic governance. Part of this transition process included efforts to become a member of European and international political and security structures. Admittance to the Organization for Economic Co-operation and Development (OECD) in 1996 provided impetus for the resumption of development cooperation (Horký 2011). The following two decades were marked by a gradual building of institutional and legislative frameworks and, mainly in the first decade, an increase in the volume of Czech development aid. The first aim of the paper is to provide an overview of the last twenty years of Czech development assistance and analyze its territorial allocation. This overview provides the context for the main part of the research, which aims to identify factors that are significant determinants of territorial allocation of Czech development aid.

There is a lack of studies aimed at the statistical evaluation of the factors which may influence Czech development aid. Opršal, Harmáček, Syrovátka (2016) focus on the allocation of Czech aid solely to the countries of Sub-Saharan Africa and therefore this cannot be extrapolated to the entire amount of Czech development assistance. Szent-Iványi (2012) includes the four Visegrad countries (Czechia, Slovakia, Hungary and Poland) in his research and due to the limited availability of data this does not include some important factors. Beside the territorial allocation, Syrovátka, Krylová (2012) assessed Czech aid using the aid component of the Commitment to Development Index. Němečková et al. (2014) evaluated the Czech government's scholarship programme for students from developing countries. Other authors have addressed the broader aspects of Czech involvement in international development, incuding migration and remmitances (Stojanov, Strielkowski, Drbohlav 2011).

\section{Czechia as a re-emerging donor}

Czechia, together with other post-communist Central and Eastern European countries, is in the category of 'new' or 'emerging' donors (Walz, Ramachandran 2011; Zimmermann, Smith 2011). The term 'new donor' reflects the fact that the Central and Eastern European countries have established their development cooperation systems relatively recently, since the second half of the 1990s. However, these terms are partly misleading because the Central and Eastern European countries were providing assistance to Third World countries during the Cold War period (Krylová, Syrovátka, Opršal 2012). At the time, the Central and Eastern European countries were integrated into the Soviet sphere of influence, and so their 
relationships with Third World countries were, to a large extent, shaped by Soviet interests (Zídek, Sieber 2007; Leichtová, Piknerová 2013). The former Czechoslovakia was also actively engaged in assisting leftist regimes with a pro-Soviet political orientation. This includes countries from sub-Saharan Africa, Asia and Latin America, and the intensity of cooperation during the forty years of Czechoslovak assistance fluctuated, depending on the domestic and international political situation at the time. The extent of Czechoslovak assistance was quite substantial. According to Staar (1982), the volume of aid from communist Czechoslovakia was higher than the total amount of aid from all the other Eastern Bloc countries (not including the USSR).

The fall of the communist regime and the subsequent political and economic transition of Czechia resulted in the temporary suspension of Czech foreign aid. Czechia and other post-communist countries became recipients of development aid. The situation has changed due to the Czech involvement with the Organization for Economic Co-operation and Development (OECD), the Bretton Woods institutions and the European Union (EU). According to Horký (2011: 122), the effort to enter 'the club of the rich' resulted in the acceptance of international commitments to once again provide development aid, albeit "as part of the accession package". Meanwhile, public opinion has changed and become more favorable towards humanitarian and development aid as a reaction to the humanitarian efforts of Czech non-govermental organisations in the war-torn Balkan countries (Grimm, Harmer 2005).

Accession to the European Union in 2004 led to the convergence of the Czech legislation with the acquis communautaire and that influenced Czech development policy (Horký, Lightfoot 2012). The transformation has changed the institutional and legal arrangements of the Czech development aid system to its present form. The Development Cooperation and Humanitarian Aid Act (Zákon č. 151/2010 Sb.), adopted in 2010, has defined the concepts of development cooperation and humanitarian aid, as well as the roles of various actors in its implementation. The responsibility for most of the bilateral Official Development Assistance (ODA) has been transferred from nine ministries to the Ministry of Foreign Affairs (MFA). The implementation body of Czech Development Cooperation is the Czech Development Agency, which is primarily focused on the design and execution of bilateral development projects (MFA 2013). The evolution of Czech ODA symbolically culminated in 2013 when Czechia became the $26^{\text {th }}$ member of the DAC; the OECD's Development Assistance Committee (OECD 2016). Membership of the influential club of the most advanced western donors does not however, automatically mean that the country follows all the rules of 'good donorship' and provides more effective aid. Despite some progress in institutional and legislative measures, challenges remain in the areas of political and public support, in the quantity and quality of aid and in the selection of partner countries. 


\section{Territorial aspects of Czech aid}

Since the re-establishment of Czech development cooperation, the territorial distribution of Czech aid had been subject to changes. At first, the Czech aid system suffered from a lack of clearly defined priorities and this resulted in considerable territorial and sectoral fragmentation of Czech development assistance. In the period 1996-2000, development projects financed by the Czech government were implemented in more than 40 countries (Exnerová 2005). This situation was hardly tenable, especially when considering the low volume of overall aid flows at that time, which severely diminished the aid's effectiveness. Therefore, a new strategy adopted by the Czech government in 2002 (MFA 2002) reduced the number to 20 countries on which development cooperation funds were to be primarily focused. Nevertheless, even the limited number of 20 priority countries was too ambitious for Czechia, which is a small donor. Therefore, new Principles of Development Cooperation, implemented after the Czechia's Accession to the EU (MFA 2004), further reduced the number, setting the number of "programme countries" (countries with a cooperation programme) at eight and the number of "medium-term priority countries" at two. Although the selection process was intended to be transparent and based on a pre-defined set of criteria, the final list only partially respected the criteria and has been subject to political influences and ad-hoc decisions (Horký 2011). The list of 10 partner countries was later extended by four under the newly created category of "project countries", increasing the total number of partner countries to 14 (Table 1).

Adoption of the Development Cooperation Strategy 2010-2017 brought the last revision of territorial priorities. With regard to the recommendations of the special review of the OECD/DAC (OECD 2007), the government decreased the number of programme countries from 8 to 5 . In addition to priority countries with a cooperation programme, the government decided to maintain the group of "project countries" (with a modified composition) where Czech development activities were based on freestanding projects. Including the group of countries in which Czech development activities are being phased out, the total number of partner countries in the current period exceeds the recommendations of the OECD/DAC and the World Bank. It is doubtful whether this arrangement will help overcome one of the shortcomings identified in Strategy; the fragmentation of Czech development cooperation (MFA 2012).

Szent-Iványi (2012) divided the partner countries of the four Visegrad members into three broad groups: (i) countries in the immediate neighbourhood (western Balkans and the CIS region), (ii) Iraq and Afghanistan and (iii) partner countries 'inherited' from the Communist period. A closer look at the data from the OECD's StatExtracts online database confirms this assertion. The top two recipients of Czech official development aid in the period 1998-2013 were Afghanistan and 
Table 1 - Territorial priorities of Czechia in the periods 2006-2010 and 2011-2017

\begin{tabular}{|c|c|c|c|}
\hline \multicolumn{2}{|c|}{ Territorial priorities in the period of 2006-2010 } & \multicolumn{2}{|c|}{ Territorial priorities in the period of 2011-2017 } \\
\hline Programme Countries (8) & $\begin{array}{l}\text { Angola, Bosnia and } \\
\text { Herzegovina, Yemen, } \\
\text { Moldova, Mongolia, Serbia, } \\
\text { Vietnam, Zambia }\end{array}$ & Programme Countries (5) & $\begin{array}{l}\text { Afghanistan, Bosnia and } \\
\text { Herzegovina, Ethiopia, } \\
\text { Moldova, Mongolia }\end{array}$ \\
\hline $\begin{array}{l}\text { Medium-term priority } \\
\text { countries ( } 2 \text { ) }\end{array}$ & Afghanistan, Iraq & Project Countries (5) & $\begin{array}{l}\text { Georgia, Cambodia, } \\
\text { Kosovo, Palestinian } \\
\text { Autonomous Territories, } \\
\text { Serbia }\end{array}$ \\
\hline Project Countries (4) & $\begin{array}{l}\text { Cambodia, Palestinian } \\
\text { Autonomous Territories, } \\
\text { Kosovo, Ethiopia }\end{array}$ & Phase out Countries (4) & $\begin{array}{l}\text { Angola, Yemen, Vietnam, } \\
\text { Zambia }\end{array}$ \\
\hline \multicolumn{2}{|c|}{ Total number of partner countries: 14} & \multicolumn{2}{|c|}{ Total number of partner countries: 14} \\
\hline
\end{tabular}

Source: Sládková (2011), MFA (2002), MFA (2012)

Iraq (OECD 2015b). Aid to these countries is based on international obligations as a NATO member (Szent-Iványi 2012) and represents the special securitydevelopment priorities of Czech aid (MFA 2012). The western Balkan countries and the CIS region have five of the top ten recipients (Serbia, Ukraine, Bosnia and Herzegovina, Moldova and Georgia). A broad variety of motives drives the flow of Czech aid to these countries. The stability of countries in relative proximity to Czechia seems to be one of the reasons, while others include economic, cultural and historical ties. The three remaining countries on the list of the ten largest recipients are Mongolia, Vietnam and Ethiopia. The first two are representatives of partner countries 'inherited' from the communist period and the Czech government envisages a gradual reduction of aid provided to them (MFA 2012). In contrast, development assistance to Ethiopia is supported and is on an upward trend - undoubtedly because it represents the only country from sub-Saharan Africa among the territorial priorities of Czechia.

Overall, the current Czech bilateral aid flows are relatively focused on priority countries - eight of its priority countries were among its top ten recipients in 2013 (OECD 2015a) and all ten priority countries received $60 \%$ of country-allocable ODA (2012-2013 average). On the other hand, the rest of the country-allocable ODA is dispersed among more than one hundred developing countries (OECD 2015a).

Figure 1 shows the amount of Czech ODA provided to developing countries in the period 1996-2013. The cluster of long-term priority countries in the vicinity of Central Europe is clearly visible, together with other significant recipients (notably Afghanistan and Iraq). In the sub-Saharan Africa region, only a few countries Ethiopia, Angola, Zambia and Namibia - received significant amounts of Czech aid. In this respect, Opršal, Harmáček, Syrovátka (2016) showed that the amount of 


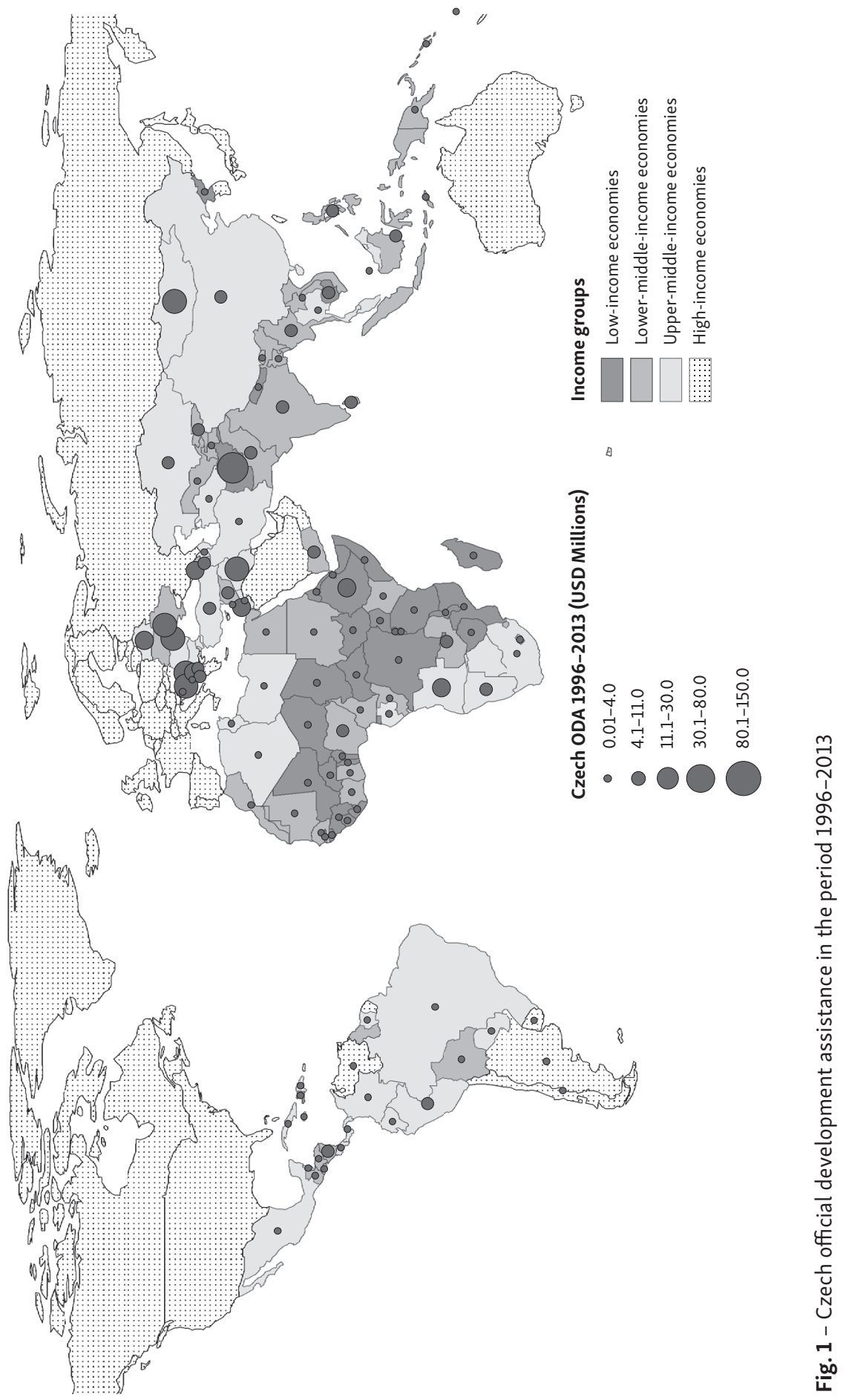




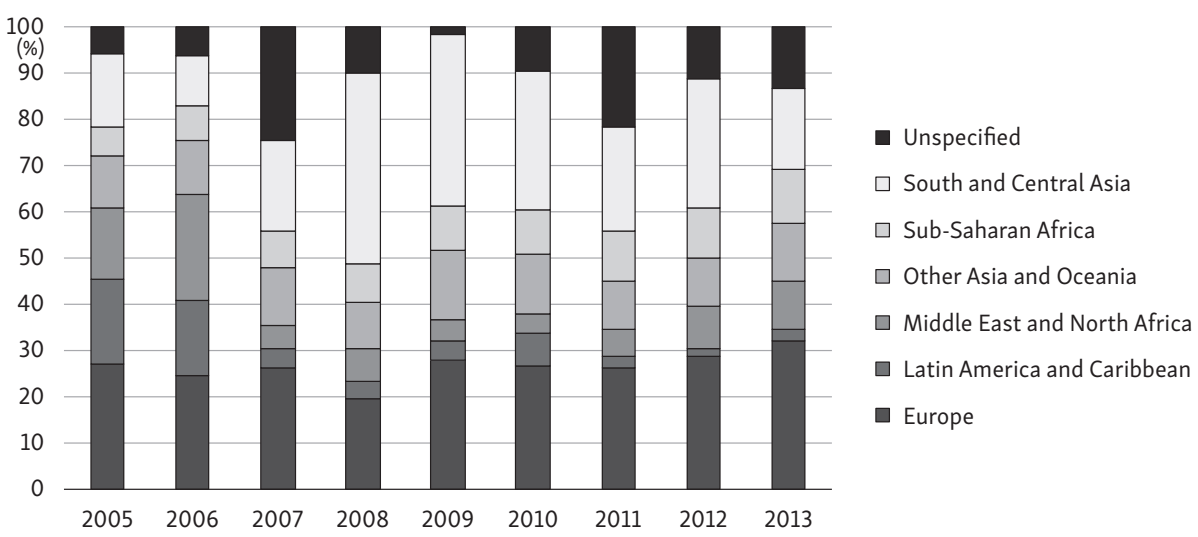

Fig. 2 - The trends in the territorial allocation of Czech bilateral official development assistance in the period 2005-2013 (in \%). Source: based on OECD.Stat (OECD, 2015b).

Czech aid flowing to individual sub-Saharan Africa countries is significantly influenced by the historical relationships between the former Czechoslovakia and the sub-Saharan Africa countries prior to 1989. Figure 2 reveals the trends in regional preferences of Czech aid flows. The decrease in bilateral aid to south and central Asia is clearly observable, although the regions still received a significant share of Czech aid (23\% in 2013; OECD 2015a). This decline was brought about by the rising share of aid to Europe, which is currently the top recipient with aid amounting to $30 \%$ of Czech bilateral ODA in 2013. The Middle East and North Africa is another region with a growing significance, mainly due to the humanitarian aid provided to Syria and neighbouring countries affected by the armed conflict and the refugee crisis. In 2013, this region's share of aid was $10 \%$ of the total Czech bilateral ODA, similar to the share of Asia and Oceania (11\%) and of sub-Saharan Africa (11\%; OECD 2015a). Latin America and the Caribbean is a region of peripheral interest to Czech development cooperation (1\% of Czech ODA in 2013).

Regarding countries' income categorisation, $21 \%$ of bilateral ODA was allocated to the least developed countries in 2013 (lower figure than the 2013 DAC average of $31 \%)$, while lower-middle income countries (40\%) and upper-middle income countries (39\%) received the largest share of Czech bilateral ODA (OECD 2015a). The relatively low share of Czech aid to the least developed countries has been criticised by nongovernmental organizations (Mihálik et al. 2010) and does not correspond with international efforts and commitments (UNCTAD 2015). On the other hand, Czechia states that it is trying to utilise its "experience of the process of political, economic and social transformation" (MFA 2012,17). This may be one of the factors which affects the flow of Czech aid towards middle-income countries in Eastern Europe (Krylová, Syrovátka, Opršal 2012). 
The overview above provides a useful starting-point for an understanding of territorial preferences and trends in Czech development assistance, thought it cannot fully reveal the variety of factors which may influence the actual distribution of Czech aid. The following sections deals with this by employing a regression analysis of Czech aid allocation.

\section{Analysis of factors affecting aid allocation}

The aim of the second part of our research is to find the factors that are significant determinants of territorial allocation of Czech ODA in 156 developing countries over the period 1998-2013. Specifically, we want to ascertain whether the factors approximating Czech interests in recipient countries and those recipient countries' needs are significant determinants of Czech aid allocation. For this, we performed a tobit panel data analysis and considered both the selfish and the altrusitic factors behind aid allocation.

\subsection{Theory and factors of aid allocation}

The factors which determine aid allocation are usually divided into two groups: factors describing developing countries' needs and factors approximating donors' interests. The older approach to aid allocation research, known as the recipient need-donor interest approach, examines factors of aid allocation separately (see, for example, McKinlay, Little 1979; Maizels, Nissanke 1984). The methodology of these studies was later questioned: it was argued that examining the factors with two separate regression equations generated biased results (e.g. Bowles 1987; Poe, Sirirangsi 1993). Therefore, a second approach to aid allocation research evolved. It is known as a 'hybrid' because it integrates the factors which represent developing countries' needs and donors' interests (and possibly other factors) in one regression equation (McGillivray 2003). This approach has been used in practically all recent studies of aid allocation factors (including our study).

Factors which approximate donors' interests are usually related to measures of bilateral trade with, or donors' exports to, recipient countries (Alesina, Dollar 2000; Berthélemy 2006; Canavire et al. 2005; Lundsgaarde, Breunig, Prakash 2010 etc.). Additionally, variables which describe special relationships between a donor and a recipient are also used in this regard, such as dummy variables for common colonial links (Schraeder Hook, Taylor 1998 and many others) and dummy variables for special Japanese ties to Asia (Berthélemy 2006) or special US ties to Egypt or Israel (Alesina, Dollar 2000). Variables which measure geographical proximity (i.e. distance, Collier, Dollar 2004), language proximity (Lundsgaarde et al. 2010), 
and religious or cultural proximity (Alesina, Dollar 2000; Younas 2008) between a donor and a recipient also fall into this category. The theory predicts that the more intense the donors' interests and the closer the mutual relationships, the higher the volume of aid will be from the donor to that particular recipient. These assumptions are usually confirmed by empirical results.

The factors used to measure the needs of recipient countries (i.e. the altruistic motives of aid allocation) can be divided into three broad groups: economic, social and institutional (and/or political). The economic needs of recipients are usually measured by the level of economic development, i.e. by GDP per capita or similar variables (Harrigan, Wang 2011 and many others). Social needs are described by indicators of social development, such as the infant mortality rate (Berthélemy, Tichit 2004), caloric intake (Schraeder, Hook, Taylor 1998) and literacy rate (Lundsgaarde, Breunig, Prakash 2010). The total population of recipients must also be controlled, as larger numbers of poor people in developing countries are likely to be in greater need of aid (ceteris paribus, Neumayer 2003). The theory predicts that higher volumes of aid are associated with greater recipients' needs (Berthélemy 2006 and many others). However, the empirical evidence to support this theory of altruism in aid allocation is weaker than in the case of selfish donor motives.

Recently, attention has been paid to the institutional (and/or political) factors of aid allocation. According to one theory, in order to achieve higher aid efficiency, donors should reward the better institutional performances of recipients with higher volumes of aid (Burnside, Dollar 2000). However, the issue of using institutional quality in aid allocation research lies in its approximation with data. For example, according to Canavire et al. (2005), the significance of institutional quality as a determinant of aid depends on the variables used to measure it. Therefore in aid allocation studies, institutional quality is sometimes supplemented (or even entirely replaced) by indicators which approximate political development, such as the level of civil liberties and political rights (Berthélemy, Tichit 2004) or the type of political regime (Lundsgaarde, Breunig, Prakash 2010). However, in this respect, the empirical results are rather ambiguous.

\subsection{Our variables and data}

In our study, we examine various factors that affected the territorial allocation of Czech ODA in 156 developing countries over the period 1998-2013. We define developing countries, in accordance with the OECD DAC, as countries that were eligible recipients of ODA at any time over the defined period. We make use of panel data with a cross-section element of 156 countries and a time frame of 16 years. Potentially, this produces 2,496 data points (156 times 16 ) for each variable. However, as 
there are missing data for many variables, our models work with between 1,700 and 1,900 observations.

The dependent variable is the volume of Czech gross ODA at the constant prices of 2014 (in USD) disbursed to individual countries as recorded by the statistical database OECD.Stat (OECD 2015b). We use the variable in logarithmic form to reduce its skew and the risk of possible heteroskedasticity.

In accordance with the theory discussed above, our independent variables can be divided into three groups. The first group contains variables which approximate Czech interests in a given developing country and variables which reflect the relationship between Czechia and a given recipient. We use the volume of Czech exports and the volume of bilateral trade with recipients (constant prices of 2010) to measure Czech economic interests. To reflect both economic and political interests, we work with a dummy variable which indicates the presence of a Czech embassy in a given country. To account for a special historical relationship between Czechia and a recipient, we employ a dummy variable which indicates whether a country was a member, associate member, observer or closely cooperated with the Council for Mutual Economic Assistance (COMECON). We also use a variable to measure the geographical distance between Czechia and recipients. We hypothesize that the volume of Czech aid allocation should increase with a higher volume of exports (trade), the presence of a Czech embassy, a close historical relationship and closer geographical proximity.

The second group includes variables that reflect the altruistic motives of aid allocation: either the need for aid of a given recipient country (economic and social underdevelopment, as measured by GDP per capita, life expectancy at birth, mean years of schooling, under-5 mortality rate and population size) or the recipient's institutional quality and political development. In this regard, we employ the Index of Freedom (Freedom House 2015), which we use alternately with (a) a combination of two variables; one measures the level of civil liberties and the second measures the type of political regime, and with (b) an average of six Worldwide Governance Indicators (World Bank 2015b) that quantitatively approximate a more broadly defined concept of institutional quality. We hypothesize that the higher the need for aid (as measured by indicators of economic and social development), the higher the magnitudes of aid should be. We also expect that countries with better institutions and countries that are more democratic and free should receive more aid.

The third group comprises variables which measure the special effects related to aid allocation. By including the total amount of ODA of all DAC members, we deal with the so-called bandwagon effect, according to which, donors are likely to provide more aid to recipients where other bilateral donors are already present (Harrigan, Wang 2011). We also include a lagged dependent variable among regressors to take into account the inertia in policy decision-making related to aid allocation. The variables we use in our analysis are summarized in Table 2. 
Table 2 - Description of variables

\begin{tabular}{|c|c|c|c|}
\hline $\begin{array}{l}\text { Name used in } \\
\text { regressions }\end{array}$ & Description & Unit & Source \\
\hline $\begin{array}{l}\text { CZAid1 } \\
(\ln , \mathrm{L} 1)\end{array}$ & Czech ODA (to a given country) & $\begin{array}{l}\text { USD, gross ODA disbursements, } \\
\text { constant prices } 2014\end{array}$ & $\operatorname{OECD}(2015 b)$ \\
\hline $\begin{array}{l}\text { export_cp } \\
(\ln , \mathrm{L} 1)\end{array}$ & Czech export (to a given country) & USD, constant prices 2010 & $\begin{array}{l}\text { United Nations } \\
\text { (2016) }\end{array}$ \\
\hline $\begin{array}{l}\text { trade_cp } \\
(\ln , \mathrm{L} 1)\end{array}$ & $\begin{array}{l}\text { Czech bilateral trade (with } \\
\text { a given country) }\end{array}$ & USD, constant prices 2010 & $\begin{array}{l}\text { United Nations } \\
(2016)\end{array}$ \\
\hline $\begin{array}{l}g d p \_p c \\
(\ln , L 1)\end{array}$ & GDP per capita (of recipients) & $\begin{array}{l}\text { international dollars in purchasing } \\
\text { power parity, constant prices } 2011\end{array}$ & World Bank (2015a) \\
\hline $\begin{array}{l}\text { popul } \\
(\ln , L 1)\end{array}$ & Total population (of recipients) & thousands of inhabitants & World Bank (2015a) \\
\hline $\begin{array}{l}\text { life } \\
(\ln , L 1)\end{array}$ & $\begin{array}{l}\text { Life expectancy at birth } \\
\text { (of recipients) }\end{array}$ & years & World Bank (2015a) \\
\hline $\begin{array}{l}\text { myed } \\
(\ln , \mathrm{L} 1)\end{array}$ & $\begin{array}{l}\text { Mean years of schooling } \\
\text { (of recipients) }\end{array}$ & years & UNDP (2015) \\
\hline $\begin{array}{l}\text { u5mort } \\
(\ln , \mathrm{L} 1)\end{array}$ & $\begin{array}{l}\text { Under-5 mortality rate } \\
\text { (of recipients) }\end{array}$ & $\begin{array}{l}\text { deaths (of children younger than } \\
5 \text { years) per } 1,000 \text { live births }\end{array}$ & World Bank (2015a) \\
\hline $\begin{array}{l}\text { civlib } \\
\text { (L1) }\end{array}$ & Civil liberties (of recipients) & $\begin{array}{l}\text { index, values from } 1 \text { (best) to } \\
7 \text { (worst) }\end{array}$ & $\begin{array}{l}\text { Freedom House } \\
(2015)\end{array}$ \\
\hline $\begin{array}{l}\text { freedom } \\
\text { (L1) }\end{array}$ & Index of Freedom (of recipients) & $\begin{array}{l}\text { index, average of two sub-indices: } \\
\text { political rights and civil liberties, } \\
\text { values from } 1 \text { (most free) to } \\
7 \text { (least free) }\end{array}$ & $\begin{array}{l}\text { Freedom House } \\
(2015)\end{array}$ \\
\hline $\begin{array}{l}\text { WGI_avg } \\
\text { (L1) }\end{array}$ & $\begin{array}{l}\text { Worldwide Governance Indicators } \\
\text { (WGI) (of recipients) }\end{array}$ & $\begin{array}{l}\text { average of six sub-indicators, } \\
\text { values from }-2,5 \text { (worst) to } \\
2,5 \text { (best) }\end{array}$ & World Bank (2015b) \\
\hline $\begin{array}{l}\text { polreg } \\
(\mathrm{L} 1)\end{array}$ & Political regime (of recipients) & $\begin{array}{l}\text { Values from - } 10 \text { (strong autocracy) } \\
\text { to } 10 \text { (stable democracy) }\end{array}$ & Polity IV (2015) \\
\hline rvhp & $\begin{array}{l}\text { Historical relation with the } \\
\text { Council for Mutual Economic } \\
\text { Assistance (COMECON) }\end{array}$ & $\begin{array}{l}\text { dummy }(=1 \text {, if a recipient was } \\
\text { a member, associate member, } \\
\text { observer or cooperated with } \\
\text { COMECON) }\end{array}$ & Zwass (1989) \\
\hline dist & $\begin{array}{l}\text { Distance between Prague and the } \\
\text { capital of a given country }\end{array}$ & kilometres & $\begin{array}{l}\text { Mayer, Zignago } \\
(2011)\end{array}$ \\
\hline embassy & $\begin{array}{l}\text { Czech embassy (in a given } \\
\text { country) }\end{array}$ & $\begin{array}{l}\text { dummy ( }=1 \text {, if Czech embassy } \\
\text { present in a given country) }\end{array}$ & MFA (2015) \\
\hline $\begin{array}{l}\text { DACoda } \\
(\ln , \mathrm{L} 1)\end{array}$ & $\begin{array}{l}\text { Total ODA of all DAC countries } \\
\text { (to a given recipient) }\end{array}$ & $\begin{array}{l}\text { USD, gross ODA disbursements, } \\
\text { constant prices } 2014\end{array}$ & $\operatorname{OECD}(2015 b)$ \\
\hline
\end{tabular}

Notes:

ODA means Official Development Assistance. L1 means that the variable used in regressions was lagged by one period (year) which holds true for all time-variant variables except embassy. In means that the variable entered regressions in a logarithmic form. Since the logarithm of zero is not defined and we wanted to include zero aid allocations (i.e. a given donor does not provide any aid to a given recipient) in our analysis, we gave all zero allocations a value of 1 (i.e. 1 USD), which meant that, after the logarithmic transformation, the dependent variable In_CZAid1 took the value of 0 for all such observations. 


\subsection{Choice of an appropriate model}

In aid allocation literature there are two broad categories of econometric methods that have been used to deal with 'hybrid' models. The distinction between these two categories lies in the way zero aid allocations (i.e. a given donor does not provide any aid to a given recipient) are treated. If the zero allocations are ignored, ordinary least squares methods or panel data techniques such as pooled ordinary least squares, random effects or fixed effects estimations are used (Harmáček, Syrovátka, Opršal 2017). These methods may be employed when there is no significant amount of zero allocations, or better to say, when ignoring the zero allocations does not lead to a significant bias in estimations (for application, see Alesina, Dollar 2000; Schraeder, Hook, Taylor 1998; Tuman, Strand, Emmert 2009; Younas 2008; Harrigan, Wang 2011).

The second category of methods takes the zero aid allocations into account. There are at least three methods that can be used to work with the truncated (censored) dependent variable. First, a two-part model estimates the factors present in the selection of recipients in the first step (i.e. whether aid is provided at all to a given recipient). In the second step, factors of non-zero aid allocations are estimated. Since both steps must be independent, this method is not frequently used in practice (for application, see Barthel et al. 2013; Berthélemy 2006).

The second option is the heckman model, which is also a two-part model. However, it does not require the selection and allocation steps to be independent. Neverthless, its use depends heavily on the existence of an 'identifying restriction', i.e. on identifying at least one variable that is significant for selection but insignificant for allocation. In reality, it is very difficult to find such an instrument in aid allocation, so the use of the heckman method is not very common (for application see Lundsgaarde, Breunig, Prakash 2010; Berthélemy 2006).

The third possibility, which takes the truncated nature of the dependent variable into account, is the tobit model. Unlike the two previous methods, this is a one-step model that does not allow the factors of selection and allocation to be estimated separately, i.e. it is based on the assumption that all factors affect both steps in the same direction (which, however, seems to be quite plausible in an aid allocation framework). Similar to the first category of methods (that ignore the truncated nature of the dependent variable), tobit models are frequently used in aid allocation research (for application see for example Dreher et al. 2009; Canavire et al. 2005; Berthélemy, Tichit 2004).

Based on the following criteria, we have decided to employ the tobit model in our analysis. First, in Czech aid allocation over the period 1998-2013, there is a significant amount of zero aid allocations (approximately $51 \%$ of the observations of the dependent variable equal zero). This means that we have to take the truncated nature of the dependent variable into account. Second, based on the econometric 
theory, the heckman model may be considered as superior to the tobit option. We followed Lundsgaarde, Breunig, Prakash (2010) and tried to use the historical relationship variable ( $r v h p$ ) and the presence of a Czech embassy (embassy) as our identifying restrictions. If they were appropriate instruments, they would affect selection but not allocation. We ran regressions on non-zero aid allocations and found that statistically both variables were highly significant determinants of (non-zero) aid allocations. Therefore, it was not possible to use them as our instruments - and since it is generally difficult to find such instruments, we decided to use the tobit method. Moreover, the tobit model can be used smoothly with panel data, although only with random effects. So, our default model can be written as ( $t$ stands for time, $i$ stands for a particular recipient, $\varepsilon$ is the error term):

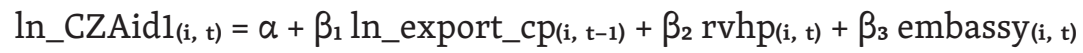

$+\beta_{4} \operatorname{dist}_{(\mathrm{i}, \mathrm{t})}+\beta_{5} \ln \_g d p \_p c(\mathrm{i}, \mathrm{t}-1)+\beta_{6} \ln \_$popul $(\mathrm{i}, \mathrm{t}-1)+\beta_{7} \ln \_$life $(\mathrm{i}, \mathrm{t}-1)$

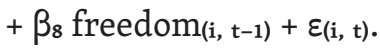

\section{Results and discussion}

Apart from our default model, we have run a variety of tobit regressions in which we alternated different indicators within particular groups of factors as outlined above. We have also accounted for the special effects of aid allocations in these regressions. The complete results from eight models that represent the variety of regressions we have performed are presented in Table 3.

In Table 4, we summarize the independent variables, the hypothesized relationships between the dependent variables and the independent variables, and the outcomes of our analysis, i.e. whether the hypothesized relationships have been confirmed (ceteris paribus). While the models yield some diversity of results, most of the hypothesized relationships have been confirmed.

The variables which measure Czech interests in recipient countries are significant determinants of aid allocation. In particular, the volume of Czech exports (or bilateral trade) is a positive factor in Czech aid allocation: Czechia gives more aid to those countries to which it exports more (or with which it trades more). Likewise, Czechia tends to provide more aid to countries with which it has closer historical relationships and to countries that are in its geographical proximity. On the other hand, the presence of a Czech embassy in a recipient country is not a statistically significant determinant of allocation.

As for the recipient countries' characteristics (i.e. the altruistic motives), we have found that Czechia allocates more aid to the more populous countries. However, interesting results have been obtained for the two factors which approximate the need for aid of the recipients. The analysis shows that Czechia's aid allocation 
Table 3 - Regression models and results

\begin{tabular}{|c|c|c|c|c|c|c|c|c|}
\hline \multirow[b]{2}{*}{\begin{tabular}{l} 
Variables \} $\\
{\text { Models }}$ & \multicolumn{8}{|c|}{ Dependent variable: In_CZAid1 } \\
\hline & (1) & $(2)$ & (3) & (4) & (5) & (6) & (7) & (8) \\
\hline In_export_cp_L1 & $\begin{array}{l}0.613^{* * *} \\
(0.177)\end{array}$ & & $\begin{array}{l}0.568^{* * *} \\
(0.192)\end{array}$ & $\begin{array}{l}0.658^{* * *} \\
(0.189)\end{array}$ & $\begin{array}{l}0.635^{* * *} \\
(0.187)\end{array}$ & $\begin{array}{l}0.402^{* *} \\
(0.193)\end{array}$ & $\begin{array}{l}0.468^{* * *} \\
(0.164)\end{array}$ & $\begin{array}{c}0.160 \\
(0.133)\end{array}$ \\
\hline In_trade_cp_L1 & & $\begin{array}{l}0.623^{* * *} \\
(0.201)\end{array}$ & & & & & & \\
\hline rvhp & $\begin{array}{l}3.855^{* *} \\
(1.527)\end{array}$ & $\begin{array}{l}3.900^{* *} \\
(1.533)\end{array}$ & $\begin{array}{l}3.960 * * \\
(1.543)\end{array}$ & $\begin{array}{c}2.834^{*} \\
(1.453)\end{array}$ & $\begin{array}{l}3.100^{* *} \\
(1.457)\end{array}$ & $\begin{array}{c}3.087^{*} \\
(1.737)\end{array}$ & $\begin{array}{l}2.793^{* *} \\
(1.149)\end{array}$ & $\begin{array}{l}1.771^{* * *} \\
(0.662)\end{array}$ \\
\hline embassy & $\begin{array}{c}1.255 \\
(0.806)\end{array}$ & $\begin{array}{c}1.174 \\
(0.806)\end{array}$ & $\begin{array}{c}1.210 \\
(0.818)\end{array}$ & $\begin{array}{l}1.766^{* *} \\
(0.815)\end{array}$ & $\begin{array}{c}0.847 \\
(0.822)\end{array}$ & $\begin{array}{c}1.188 \\
(0.823)\end{array}$ & $\begin{array}{c}1.195 \\
(0.735)\end{array}$ & $\begin{array}{c}0.958^{*} \\
(0.563)\end{array}$ \\
\hline dist & $\begin{array}{l}-0.0005^{* *} \\
(0.0002)\end{array}$ & $\begin{array}{l}-0.0006^{* * *} \\
(0.0002)\end{array}$ & $\begin{array}{l}-0.0005^{* *} \\
(0.0002)\end{array}$ & $\begin{array}{l}-0.0003 \\
(0.0002)\end{array}$ & $\begin{array}{l}-0.0005^{* *} \\
(0.0002)\end{array}$ & $\begin{array}{c}-0.0005^{* *} \\
(0.002)\end{array}$ & $\begin{array}{l}-0.0006^{* * *} \\
(0.0002)\end{array}$ & $\begin{array}{l}-0.0002^{* *} \\
(0.0001)\end{array}$ \\
\hline ln_gdp_pc_L1 & $\begin{array}{l}-3.628^{* * *} \\
(0.726)\end{array}$ & $\begin{array}{l}-3.584^{* * *} \\
(0.739)\end{array}$ & $\begin{array}{l}-2.963^{* * *} \\
(0.759)\end{array}$ & $\begin{array}{l}-2.250^{* * *} \\
(0.735)\end{array}$ & $\begin{array}{l}-2.167^{* * *} \\
(0.712)\end{array}$ & $\begin{array}{l}-4.956^{* * *} \\
(0.902)\end{array}$ & $\begin{array}{l}-1.999 * * * \\
(0.637)\end{array}$ & $\begin{array}{l}-0.039 * * * \\
(0.393)\end{array}$ \\
\hline In_popul_L1 & $\begin{array}{l}2.381^{* * *} \\
(0.408)\end{array}$ & $\begin{array}{l}2.288^{* * *} \\
(0.431)\end{array}$ & $\begin{array}{l}2.629^{* * *} \\
(0.493)\end{array}$ & $\begin{array}{l}1.907^{* * *} \\
(0.454)\end{array}$ & $\begin{array}{l}2.167^{* * *} \\
(0.450)\end{array}$ & $\begin{array}{l}3.130^{* * *} \\
(0.531)\end{array}$ & $\begin{array}{l}1.073^{* * *} \\
(0.367)\end{array}$ & $\begin{array}{l}0.881^{* * *} \\
(0.219)\end{array}$ \\
\hline In_life_L1 & $\begin{array}{l}0.434^{* * *} \\
(0.076)\end{array}$ & $\begin{array}{l}0.431^{* * *} \\
(0.076)\end{array}$ & $\begin{array}{l}0.387^{* * *} \\
(0.077)\end{array}$ & $\begin{array}{l}0.412^{* * *} \\
(0.074)\end{array}$ & & & $\begin{array}{l}0.355^{* * *} \\
(0.064)\end{array}$ & $\begin{array}{l}0.114^{* * *} \\
(0.039)\end{array}$ \\
\hline In_myed_L1 & & & & & $\begin{array}{l}5.964^{* * *} \\
(1.317)\end{array}$ & & & \\
\hline ln_u5mort_L1 & & & & & & $\begin{array}{l}-6.952^{* * *} \\
(1.030)\end{array}$ & & \\
\hline freedom_L1 & $\begin{array}{l}-0.832^{* * *} \\
(0.268)\end{array}$ & $\begin{array}{l}-0.830^{* * *} \\
(0.269)\end{array}$ & & & & & $\begin{array}{l}-0.528^{* *} \\
(0.235)\end{array}$ & $\begin{array}{l}-0.243 \\
(0.156)\end{array}$ \\
\hline civlib_L1 & & & $\begin{array}{l}-0.832^{* *} \\
(0.343)\end{array}$ & & & $\begin{array}{l}-0.783^{* *} \\
(0.345)\end{array}$ & & \\
\hline polreg_L1 & & & $\begin{array}{l}0.267^{* * *} \\
(0.078)\end{array}$ & $\begin{array}{l}0.461^{* * *} \\
(0.070)\end{array}$ & $\begin{array}{l}0.444^{* * *} \\
(0.069)\end{array}$ & $\begin{array}{l}0.238^{* * *} \\
(0.079)\end{array}$ & & \\
\hline WGI_avg_L1 & & & & $\begin{array}{l}-4.403^{* * *} \\
(0.892)\end{array}$ & $\begin{array}{l}-3.357^{* * *} \\
(0.889)\end{array}$ & & & \\
\hline In_DACoda_L1 & & & & & & & $\begin{array}{l}1.641^{* * *} \\
(0.289)\end{array}$ & \\
\hline In_CZAid1_L1 & & & & & & & & $\begin{array}{l}0.799 * * * \\
(0.036)\end{array}$ \\
\hline constant & $\begin{array}{c}-18.933^{* * *} \\
(6.634)\end{array}$ & $\begin{array}{c}-18.685^{* * *} \\
(6.618)\end{array}$ & $\begin{array}{c}-23.616^{* * *} \\
(0.601)\end{array}$ & $\begin{array}{c}-33.080^{* * *} \\
(6.747)\end{array}$ & $\begin{array}{c}-17.328^{* * *} \\
(6.546)\end{array}$ & $\begin{array}{l}42.736^{* * *} \\
(11.727)\end{array}$ & $\begin{array}{c}-21.421^{* * *} \\
(5.138)\end{array}$ & $\begin{array}{c}0.394 \\
(3.02)\end{array}$ \\
\hline Wald chi2 & $192.21^{* * *}$ & $181.97^{* * *}$ & $174.77^{* * *}$ & $211.75^{* * *}$ & $193.43^{* * *}$ & $171.67^{* * *}$ & $289.81^{* * *}$ & $1,061.63^{* * *}$ \\
\hline Observations & 1,932 & 1,895 & 1,713 & 1,717 & 1,611 & 1,713 & 1,776 & 1,932 \\
\hline - censored obs. & 848 & 816 & 686 & 689 & 621 & 686 & 694 & 848 \\
\hline $\begin{array}{l}\text { No. of groups } \\
\text { (recipients) }\end{array}$ & 140 & 139 & 121 & 122 & 122 & 121 & 133 & 140 \\
\hline
\end{tabular}}
\end{tabular}

Note: Standard errors of the estimates in parentheses. ${ }^{* *}$ Significant at $1 \%$ level. ${ }^{* *}$ Significant at $5 \%$ level. * Significant at $10 \%$ level. All time-varying variables have been lagged by one time period (one year), which has been indicated by the code suffix "_L1" in the names of the variables. Model (1) is our default model. In model (2), we replaced export by bilateral trade. In models (3) and (4), we alternated different institutional and political variable compared to our default model. Models (5) and (6) used different indicators of social development compared to model (4) and (3), respectively. Models (4) and (3) were selected as the base models to concurrently control for different political and institutional variables. In model (7) we account for the bandwagon effect. Model (8) takes the inertia of policy decision-making into consideration. 


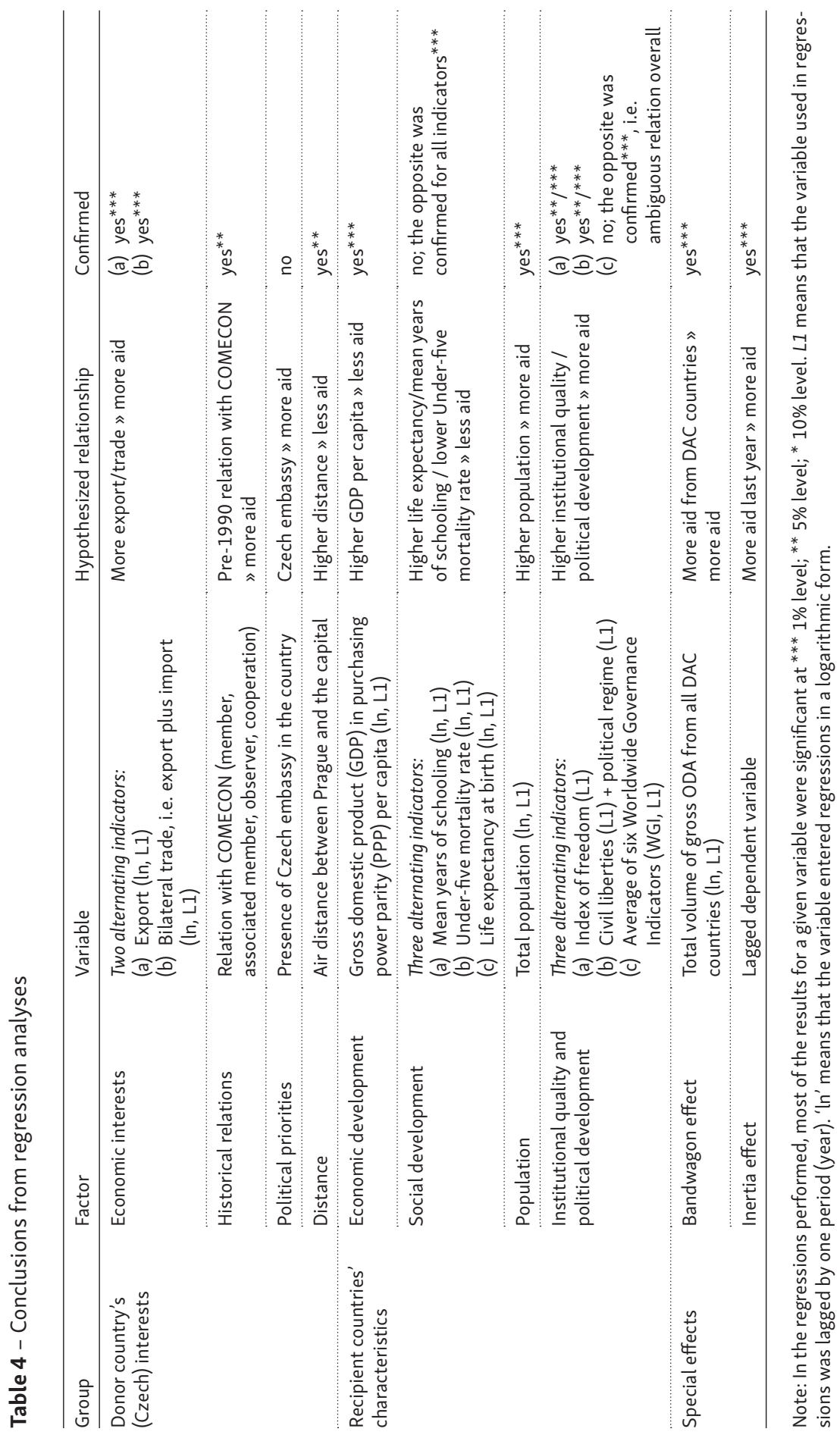


reflects the level of economic development and the level of social development of recipients in opposite directions: while Czechia tends to provide more aid to countries with lower levels of economic development, it has also a tendency to allocate more aid to recipients with a better state of health and education.

A similar contradiction can be found in the role of the recipients' institutional and political development in Czech aid allocation. If interpreted separately, it is possible to argue that in its aid allocation Czechia prefers more democratic and free countries with a lower quality of (more broadly defined) institutions. However, if these two findings are interpreted together, the conclusion about the role of the recipients' political and institutional development in Czech aid allocation remains unclear.

Finally, we have confirmed two special effects of Czech aid allocation. Czechia tended to allocate more aid to countries where other DAC donors also allocated more aid and, not surprisingly, to countries where it had previously provided aid.

We have also investigated other factors that may have influenced the allocation of Czech aid, such as the foreign debt of the recipient countries, the transformation index and the number of migrants from the recipient countries in Czechia. However, the inclusion of these variables significantly reduced the number of observations in the regression analysis and hence also the explanatory power of the models. Therefore, such factors are not presented in the figure above. Finally, there are two caveats to the interpretation of results from our regression analysis. First, all the results from the regression analysis need to be interpreted ceteris paribus, i.e. when other factors are controlled. For example, the regression analysis showed that Czechia tended to prioritize poorer developing countries over richer ones. Though this may seem to contrast with our claim that Czechia did not provide a large share of aid to low income countries, it is not a contradiction. Second, in our analysis we examined whether the identified factors are statistically significant determinants of Czech aid allocations, but we did not measure their marginal effects. That is, we cannot say whether these factors had a strong effect on aid allocation in practical terms.

\section{Conclusions}

Czechia has provided aid to less economically developed countries for two decades, although the origins of Czech engagement with Third world countries date back to the communist regime in Czechoslovakia prior to 1989. Czechia is among a handful of post-communist countries which model their aid programs on those of the more advanced western donors - members of the OECD's Development Assistance Committee (DAC). Nevertheless, the historical background and different geographical and geopolitical characteristics of Czechia have led to a distinct geographical 
orientation for Czech development cooperation. Territorial allocations of Czech aid are biased towards countries in relative proximity to Czechia, notably in the western Balkans and CIS. Apart from partner countries in the neighbourhood, there is a significant group of Czech aid recipients with whom cooperation is based on ties inherited from the communist period. Finally, there is the special case of Afghanistan, where Czech aid corresponds with international commitments.

In the empirical part we analysed the factors that were significant determinants of territorial allocation of Czech ODA in 156 developing countries over the period 1998-2013. For this purpose we have performed a variety of random effects tobit regressions. While the analysis yielded some diversity in results, most of the hypothesized relationships have been confirmed. The results show that mostly it was Czech economic and political interests which played a role in determining the allocation of Czech aid. The effects of the recipients' needs and institutional quality are rather equivocal. Finally, Czechia tended to allocate aid to countries that were recipients of aid from other DAC donors, and to countries where it had previously provided aid.

The results of the research may serve as a basis for adjustements of Czech development policy, especially in two respects. First, fragmentation remains a long-term challenge of Czech development cooperation. Concentration of aid to a smaller number of recipient countries may increase the impact of Czech aid. Second, Czech aid allocations are driven by both its economic and political interests and recipients countries' needs, and we recommend stronger focus on the latter. Prioritisation of $\mathrm{Czech}$ economic and political interests over recipients needs may undermine efficiency and sustainability of Czech aid. Finally, Czech development policy, including the territorial and thematic priorities of aid allocation, may benefit from the expertise of Czech civil society and academia.

\section{References}

ALESINA, A., DOLLAR, D. (2000): Who Gives Foreign Aid to Whom and Why? Journal of Economic Growth, 5, 1, 33-63.

BARTHEL, F., NEUMAYER, E., NUNNENKAMP, P., SELAYA, P. (2013): Competition for Export Markets and the Allocation of Foreign Aid: The Role of Spatial Dependence among Donor Countries. Kiel Working Paper No. 1875. Kiel Institute for the World Economy.

BOWLES, P. (1987): Foreign Aid and Domestic Savings in Less Developed Countries: Some Tests for Causality. World Development, 15, 6, 789-796.

BERTHÉLEMY, J.C. (2006): Bilateral Donors' Interest vs. Recipients' Development Motives in Aid Allocation: Do All Donors Behave the Same? Review of Development Economics, 10, 2, 179-1940.

BERTHÉLEMY, J.C., TICHIT, A. (2004): Bilateral Donors' Aid Allocation Decisions - A Threedimensional Panel Analysis. International Review of Economics \& Finance, 13, 3, 253-274.

BURNSIDE, C., DOLLAR, D. (2000): Aid, policies and growth. American Economic Review, $90,4,847-868$. 
CANAVIRE, G., NUNNENKAMP, P., THIELE, R., TRIVEÑO, L. (2005): Assessing the Allocation of Aid: Developmental Concerns and the Self-Interest of Donors. Working Paper No. 1253. Kiel: Kiel Institute for World Economics.

COLLIER, P., DOLLAR, D. (2004): Development Effectiveness: What Have We Learnt? The Economic Journal, 114, 496, 244-271.

DREHER, A., NUNNENKAMP, P., ÖHLER, H., WEISSER, J. (2009): Acting Autonomously or Mimicking the State and Peers? A Panel Tobit Analysis of Financial Dependence and Aid Allocation by Swiss NGOs. Working Paper No. 1486. Kiel: Kiel Institute for the World Economy.

EXNEROVÁ, V. (2005): Zahraniční rozvojová spolupráce České republiky. In: Exnerová, V. (ed.): Globální problémy a rozvojová spolupráce. Témata, o které se lidi zajímají. Člověk v tísni, společnost při ČT, o. p. s., Praha, 115-120.

FREEDOM HOUSE (2015): Freedom in the World Country Ratings, 1972-2014, https://freedomhouse.org/sites/default/files/Individual\%20Country\%20Ratings\%20and\%20Status\%2C\%20 1973-2015\%20\%28FINAL\%29.xls (25. 10. 2016).

GRIMM, S., HARMER, A. (2005): Diversity in Donorship: the Changing Landscape of Official Humanitarian Aid. Aid Donorship in Central Europe. Overseas Development Institute, London.

HARMÁČEK, J., SYROVÁTKA, M., OPRŠAL, Z. (2017) Analýza faktorů selekce a alokace české rozvojové pomoci s využitím panelových dat a metod Probit a Tobit. Politická ekonomie, 65, 2, 179-197.

HARRIGAN, J., WANG, C. (2011): A New Approach to the Allocation of Aid Among Developing Countries: Is the USA different from the Rest? World Development, 39, 8, 1281-1293.

HORKÝ, O. (2011): Depoliticization, instrumentalization and legitimacy of Czech development cooperation: A case of imposed altruism? Éthique et économique / Ethics and Economie, 8, $1,120-132$.

HORKÝ, O., LIGHTFOOT, S. (2012): From Aid Recipients to Aid Donors? Development Policies of Central and Eastern European States. Perspectives on European Politics and Society, 3, 1, 1-16.

KRYLOVÁ, P., SYROVÁTKA, M., OPRŠAL, Z. (2012): Assessing the aid effectiveness of the Czech Republic: commitment to development index and beyond. Perspectives on European Politics and Society, 13, 1, 100-116.

LEICHTOVÁ, M., PIKNEROVÁ, L. (2013): Rozvojová spolupráce východního bloku v době studené války. 1. vyd. Dokořán, Praha.

LUNDSGAARDE, E., BREUNIG, C., PRAKASH, A. (2010): Instrumental Philanthropy: Trade and the Allocation of Foreign Aid. Canadian Journal of Political Science, 43, 3, 733-761.

MAIZELS, A., NISSANKE, M.K. (1984): Motivations for Aid to Developing countries. World Development, 12, 9, 879-900.

MAYER, T., ZIGNAGO, S. (2011): Notes on CEPII's distances measures: the GeoDist Database. CEPII Working Paper, 2011, 25.

McGILliVRAY, M. (2003): Modelling Aid Allocation: Issues, Approaches and Results. Discussion Paper No. 2003/49. World Institute for Development Economics Research, Helsinki.

McKINLAY, R.D., LITTLE, R. (1979): The U.S Aid Relationship: The Test of Recipient Need and Donor Interest Models. Political Studies, 27, 2, 236-250.

MIHÁLIK, J., VESELÁ, V., JAKSA, B., WOJTALIK, M. (2010): Least but not Last? Least Developed Countries in Official Development Assistance of Visegrad Four Countries. People in Need, Prague.

MFA (2002): Overseas Development Assistance Strategy of the Czech Republic for the period 2002-2007 (Government Resolution No 91/2002 of 23 January 2002). 
MFA (2004): Principles of Development Cooperation after the Czech Republic's Accession to the EU.

MFA (2012): Development Cooperation Strategy of the Czech Republic 2010-2017, http://www. mzv.cz/file/762314/FINAL_Development_Cooperation_Strategy_2010_2017.pdf (13.7.2016).

MFA (2013): Development Cooperation and Humanitarian Aid. http://www.mzv.cz/jnp/en/ foreign_relations/development_cooperation_and_humanitarian/ (13.7.2016).

MFA (2015): Výroční zprávy a dokumenty. Ministerstvo zahraničních věcí ČR. http://www.mzv. cz/jnp/cz/zahranicni_vztahy/vyrocni_zpravy_a_dokumenty/ (8.5.2016).

NĚMEČKOVÁ, T., KRYLOVÁ, P., HORKÝ-HLUCHÁŇ, O., HEJKRLÍK, J., JÍLKOVÁ, K. (2014): The Czech government scholarship programme for students from developing countries Evaluation findings and policy reflections. Evaluation and Program Planning, 43, 83-89.

NEUMAYER, E. (2003): The Pattern of Aid Giving: The Impact of Good Governance on Development Assistance. Routledge, London.

OECD (2007): DAC Special Review of the Czech Republic. http://www.oecd.org/dac/peerreviews/45367897.pdf (15.4.2016).

OECD (2015a): Development Co-operation Report 2015: Making Partnerships Effective Coalitions for Action, OECD Publishing, Paris.

OECD (2015b): OECD.Stat. Organization for Economic Co-operation and Development, http:// stats.oecd.org/Index.aspx (5.10.2015).

OECD (2016): Czech Republic - the Development Assistance Committee's $26^{\text {th }}$ Member, http:// www.oecd.org/dac/peer-reviews/peer-review-czechrepublic.htm (15.6.2016).

OPRŠAL, Z., HARMÁČEK, J., SYROVÁTKA, M. (2016): The Allocation of Czech Foreign Aid in Sub-Saharan Africa: The Influence of Historical Relationships. Int. J. Economic Policy in Emerging Economies, 9, 4, 325-343.

POE, S.C., SIRIRANGSI, R. (1993): Human Rights and U.S. Economic Aid to Africa. International Interactions, 18, 4, 309-322.

POLITY IV (2015): Polity IV Individual Country Regime Trends, 1946-2013, http://www.systemicpeace.org/polity/polity4.htm (8.10.2016).

SCHRAEDER, P.J., HOOK, S.W., TAYLOR, B. (1998): Clarifying the Foreign Aid Puzzle: A Comparison of American, Japanese, French, and Swedish Aid Flows. World Politics, 50, 2, 294-323.

SLÁDKOVÁ, Z. (2011): Czech Republic and its Official Development Assistance, Briefing Paper 2/2011, FoRS, Praha.

STAAR, R.F. (1982): Communist Regimes in Eastern Europe, $4^{\text {th }}$ ed. Hoover Press Publication, Stanford, CA.

STOJANOV, R., STRIELKOWSKI, W., DRBOHLAV, D. (2011): Pracovní migrace a remitence: Současné trendy v době ekonomické krize. Geografie, 116, 4, 375-400.

SYROVÁTKA, M., KRYLOVÁ, P. (2012): Aid dimension of the Commitment to Development Index: Case study of the Czech Republic. International Journal of Sustainable Economy 4, 4, 323-339.

SZENT-IVÁNI, B. (2012): Aid allocation of the emerging Central and Eastern European donors. Journal of International Relations and Development, 15, 1, 65-89.

TUMAN, J.P., STRAND, J.R., EMMERT, C.F. (2009): The Disbursement Pattern of Japanese Foreign Aid: A Reappraisal. Journal of East Asian Studies, 9, 219-248.

UNCTAD (2015): The Least Developed Countries Report 2015. Transforming Rural Economies. United Nations, Geneva.

UNDP (2015): Human Development Reports: Data. United Nations Development Programme, http://hdr.undp.org/en/data (17.10.2016). 
UNITED NATIONS (2016): UN Comtrade Database, http://comtrade.un.org/data/. (6.10.2016). WALZ, J., RAMACHANDRAN, V. (2011): Brave New World. A Literature Review of Emerging Donors and the Changing Nature of Foreign Assistance, Centre for Global Development Working Paper No. 273, http://www.cgdev.org/publication/brave-new-worldliterature-reviewemerging-donors-and-changing-nature-foreign-assistance.

WORLD BANK (2015a): World Development Indicators, http://data.worldbank.org/indicator (17.10.2016).

WORLD BANK (2015b): Worldwide Governance Indicators, http://info.worldbank.org/governance/wgi/index.aspx\#home (17.10.2016).

YOUNAS, J. (2008): Motivation for Bilateral Aid Allocation: Altruism or Trade Benefits. European Journal of Political Economy, 24, 661-674.

Zákon č. 151/2010 Sb. ze dne 21. dubna 2010, o zahraniční rozvojové spolupráci a humanitární pomoci poskytované do zahraničí, http://www.czda.cz/editor/filestore/File/Zakon\%200\%20 ZRS\%20151_2010.pdf (23. 7. 2016).

ZÍDEK, P., SIEBER, K. (2007): Československo a subsaharská Afrika v letech 1948-1989. Ústav mezinárodních vztahů, Praha.

ZIMMERMANN, F., SMITH, K. (2011): More Actors, More Money, More ideas for International Development Co-operation. Journal of International Development, 23, 5, 722-738.

ZWASS, A. (1989): The Council for Mutual Economic Assistance: The Thorny Path from Political to Economic Integration. M. E. Sharpe, New York, NY; London.

\section{SHRNUTÍ}

\section{Geografie české rozvojové pomoci: kde a jak Česko pomáhá?}

Systém zahraniční rozvojové spolupráce Česka byl obnoven v roce 1996 v souvislosti se snahou o vstup do mezinárodních a evropských politických struktur. Dvacet let poskytování pomoci hospodářsky méně rozvinutým zemím světa představuje příležitost pro hodnocení zaměření, motivací a cílů české rozvojové pomoci. Česko bývá podobně jako další země střední a východní Evropy řazeno do skupiny takzvaných „nových“ nebo také „vynořujících se“ donorů. Označení Česka za nového donora však zakrývá fakt, že zahraniční pomoc zemím Třetího světa byla poskytována již v období komunistického režimu v bývalém Československu. V té době patřilo Československo mezi nejaktivnější země bývalého východního bloku co do rozsahu aktivit a objemu poskytované pomoci. Poskytování rozvojové pomoci bylo pozastaveno po roce 1989, kdy se Česko stalo naopak př́jemcem pomoci podporující demokratizaci a ekonomické reformy. Systém zahraniční rozvojové spolupráce byl obnoven v roce 1996 v rámci vstupu Česka do Organizace pro hospodářskou spolupráci a rozvoj. Následný vývoj české rozvojové pomoci byl ovlivněn několika významnými událostmi, mezi nejvýznamnější patří vstup Česka do Evropské unie v roce 2004 a transformace systému české oficiální rozvojové pomoci mezi lety 2008-2010. Symbolickým završením snahy o akceptaci Česka jako vyspělého donora byl vstup do prestižního Výboru pro rozvojovou pomoc při Organizaci pro hospodářskou spolupráci a rozvoj v roce 2013. Přes významný pokrok při budování systému zahraniční rozvojové spolupráce však některé kvantitativní a kvalitativní aspekty české pomoci nedosahují úrovně obvyklé u vyspělých dárců pomoci.

Specifický historický vývoj, geografické i geopolitické charakteristiky Česka mají dopad nejen na objem a kvalitu pomoci, ale také na teritoriální zaměření české rozvojové pomoci. Rozvojová 
pomoc směřuje zejména do zemí západního Balkánu a Společenství nezávislých států, tedy oblastí v relativní blízkosti Česka. Druhou skupinu teritoriálních priorit zastupují země „zděděné“ z období komunismu, se kterými existovaly nadstandardní vztahy před rokem 1989. Zvláštní př́pad představuje Afghánistán (a v minulosti také Irák), který patří mezi významné recipienty české pomoci z důvodu mezinárodních závazků Česka. Země ze zmíněných tř́ skupin jsou zastoupeny také v oficiálním seznamu prioritních zemí české zahraniční rozvojové spolupráce. Specifické geografické zaměření české pomoci má za následek stabilně vysoký podíl objemu pomoci plynoucí do Evropy (30 \% v roce 2013), zatímco podíl subsaharské Afriky (tedy regionu s nejvyšší mírou chudoby) se pohybuje okolo $10 \%$. To se odráží také v relativně vysokém podílu pomoci do zemí s nižšími středními př́imy ( $40 \%$ české oficiální rozvojové pomoci), zatímco nejméně rozvinuté země světa získávají jen $20 \%$ pomoci (v ostatních vyspělých dárcovských zemích sdružených ve Výboru pro rozvojovou pomoc Organizace pro hospodářskou spolupráci a rozvoj je tento podíl v průměru vyšší).

Empirická část analyzovala, jaké faktory jsou významné pro teritoriální alokace české oficiální rozvojové pomoci ve 156 rozvojových zemích za období 1998-2013. Byl použit model Tobit s náhodnými efekty s osmi různými specifikacemi. Přestože různé specifikace modelu generovaly mírně odlišné výsledky, většina předpokládaných vztahů se potvrdila. Výsledky ukazují, že v alokaci české pomoci hrají roli české ekonomické a politické zájmy. Česko poskytuje v průměru větší objemy pomoci do zemí, se kterými má historicky významné vztahy z období před rokem 1989, do kterých více exportuje (respektive se kterými více obchoduje) a které jsou v jeho geografické blízkosti. Rozporuplné je nicméně zohledňování potřeb recipientů v alokaci české pomoci: výše alokací v průměru rostou s klesající ekonomickou úrovní recipientů, naopak však klesají se snižující se úrovní sociálního rozvoje př́ijemců české pomoci. Efekt kvality institucí recipientských zemí je také nejednoznačný, což však částečně souvisí s obtížnou aproximací tohoto fenoménu. Konečně Česko má tendenci poskytovat pomoc zemím, do kterých ji poskytují i jiné země výboru DAC, a zemím, kam poskytovalo pomoc dříve. Na závěr je třeba poznamenat, že provedená analýza zkoumala, zda jsou identifikované faktory statisticky významnými determinanty alokace české pomoci, ale jejich mezní efekty (tj. jak se změní závislá proměnná v reakci na jednotkovou či procentní změnu určité nezávislé proměnné při kontrole vlivu ostatních faktorů) jsme nezkoumali. Výsledky analýz mohou nalézt uplatnění při tvorbě české rozvojové politiky a nastavování systému zahraniční rozvojové spolupráce Česka. Výzvou české rozvojové politiky zůstává fragmentace pomoci, v případě alokací pomoci lze doporučit upřednostnění potřeb př́jemců pomoci před ekonomickými a politickými zájmy Česka.

Obr. 1 Česká oficiální rozvojová spolupráce v letech 1996-2013

Obr. 2 Vývoj teritoriálních alokací české bilaterální rozvojové pomoci v letech 2005-2013 